\title{
Effect of increasing rate of insecticides on its selectivity for Trichogramma pretiosum Riley (Hymenoptera: Trichogrammatidae)
}

\section{Efeito do aumento de dose de inseticidas sobre sua seletividade para Trichogramma pretiosum Riley (Hymenoptera: Trichogrammatidae)}

\author{
Marcela Laiz Mora Grande ${ }^{1}$; Érica Caroline Braz²; Adeney de Freitas Bueno ${ }^{3 *}$; \\ Débora Mello da Silva ${ }^{4}$; Ana Paula de Queiroz ${ }^{5}$; Maurício Ursi Ventura ${ }^{6}$
}

\begin{abstract}
The present study evaluated the effect of different rates of chlorantraniliprole, chlorantraniliprole + lambda-cyhalothrin, spinosad, and chlorfenapyr on their selectivity for the pupae and adults of Trichogramma pretiosum. The negative effect of majority of the insecticides tested on most of the parasitoids was directly proportional to the rate of the insecticide applied. Chlorantraniliprole at a rate of $10 \mathrm{~g}$ a.i. ha ${ }^{-1}$ was classified as harmless (class 1) to both pupae and adults of the parasitoid. The effect of chlorantraniliprole at a rate of 20 to $50 \mathrm{~g}$ a.i. ha ${ }^{-1}$ varied from harmless (class 1) to slightly harmful (class 2) to the adults of T. pretiosum. Chlorantraniliprole $10+$ lambda-cyhalothrin at $5 \mathrm{~g}$ a.i. ha $^{-1}$ was classified as harmless (class 1 ) to the pupae and moderately harmful (class 3 ) to the adults of $T$. pretiosum. On the contrary, the highest rate of chlorantraniliprole 50 + lambda-cyhalothrin tested (i.e., $25 \mathrm{~g}$ a.i. ha ${ }^{-1}$ ) was classified as slightly harmful (class 2 ) to the pupae and harmful (class 4 ) to the adults of the parasitoid. Similarly, increasing the application rate of spinosad and chlorfenapyr also exhibited an increase in toxicity. Spinosad at a rate of $24 \mathrm{~g}$ a.i. ha $\mathrm{h}^{-1}$ was classified as slightly harmful (class 2) and harmless (class 1) to the pupae and adults of T. pretiosum, respectively. Spinosad at $96 \mathrm{~g}$ a.i. $\mathrm{ha}^{-1}$ was classified as both moderately harmful (class 3 ) and harmful (class 4 ) to the pupae of the parasitoid. Chlorfenapyr at a rate of $192 \mathrm{~g}$ a.i. ha ${ }^{-1}$ was classified as both slightly harmful (class 2 ) and moderately harmful (class 3 ) to the pupae of T. pretiosum, whereas chlorfenapyr at $336 \mathrm{~g}$ a.i. ha ${ }^{-1}$ was categorized as slightly harmful (class 3 ) and harmful (class 4 ) to the pupae. These results indicate that an increase in the rate of insecticide affected T. pretiosum negatively. Therefore, higher insecticide rates should only be adopted when strictly necessary to control the target pest, because they might compromise the biological pest control process in the field.
\end{abstract}

Key words: Biological control. Chemical control. IPM. Parasitoid.

1 Eng $^{\mathrm{a}} \mathrm{Agr}^{\mathrm{a}}$, Discente, Curso de Doutorado, Programa de Pós-Graduação em Agronomia, Departamento de Agronomia, Universidade Estadual de Londrina, UEL, Londrina, PR, Brasil. E-mail: marcelalaiz@hotmail.com

2 Discente, Curso de Graduação em Agronomia, Universidade do Norte do Paraná, UNOPAR, Londrina, PR, Brasil. E-mail: ericacbraz@gmail.com

3 Eng $^{\circ}$ Agr ${ }^{\circ}$, Dr., Pesquisador, Empresa Brasileira de Pesquisa Agropecuária, EMBRAPA Soja, Londrina, PR, Brasil. E-mail: adeney.bueno@embrapa.br

${ }^{4}$ Bióloga, Dra ${ }^{\text {a }}$ Instituto Agronômico do Paraná, IAPAR, Londrina, PR, Brasil. E-mail: deboramellosilva@gmail.com

5 Bióloga, Discente, Curso de Doutorado, Programa de Pós-Graduação em Entomologia, Universidade Federal do Paraná, UFPR, Curitiba, PR, Brasil. E-mail: anna.paullaqueiroz@hotmail.com

6 Eng $^{\circ}$ Agr ${ }^{\circ}$, Prof. Dr., Departamento de Agronomia, UEL, Londrina, PR, Brasil. E-mail: mventura@uel.br

* Author for correspondence 


\section{Resumo}

O presente estudo avaliou o efeito de diferentes taxas de clorantraniliprole, clorantraniliprole + lambdacialotrina, espinosade, e clorfenapir na seletividade para as pupas e adultos de Trichogramma pretiosum. $\mathrm{O}$ efeito negativo da maioria dos inseticidas testados nos parasitoides foi diretamente proporcional à dose do inseticida aplicado. O clorantraniliprole na dose de $10 \mathrm{~g}$ a.i. ha $\mathrm{f}^{-1}$ foi classificado como seletivo (classe 1) para pupas e adultos do parasitoide. O efeito do clorantraniliprole na dose de 20 a $50 \mathrm{~g}$ a.i. ha ${ }^{-1}$ variou de seletivo (classe 1) a levemente prejudicial (classe 2) aos adultos de T. pretiosum. Clorantraniliprole 10 + lambda-cialotrina a $5 \mathrm{~g}$ a.i. ha $^{-1}$ foi classificado como seletivo (classe 1) para as pupas e moderadamente prejudicial (classe 3) aos adultos de T. pretiosum. Ao contrário, a dose mais alta de clorantraniliprole 50 + lambda-cialotrina testada (isto é, $25 \mathrm{~g}$ a.i. ha ${ }^{-1}$ ) foi classificada como moderadamente prejudicial (classe 3) para as pupas e nociva (classe 4) para os adultos do parasitoide. Da mesma forma, o aumento da taxa de aplicação de espinosade e clorfenapir também apresentou aumento na toxicidade. $\mathrm{O}$ spinosade na dose de $24 \mathrm{~g}$ a.i. ha ${ }^{-1}$ foi classificado como levemente prejudicial (classe 2) e seletivo (classe 1) às pupas e adultos de T. pretiosum, respectivamente. Espinosade $96 \mathrm{~g}$ a.i. ha ${ }^{-1}$ foi classificado como moderadamente prejudicial (classe 3) e nocivas (classe 4) para as pupas do parasitoide. Clorofenapir 192 g a.i. ha ${ }^{-1}$ foi classificado como levemente prejudicial (classe 2) e moderadamente prejudicial (classe 3 ) às pupas de T. pretiosum, enquanto o clorfenapir a $336 \mathrm{~g}$ a.i. $\mathrm{ha}^{-1}$ foi categorizado como moderadamente prejudicial (classe 3 ) e nociva (classe 4) às pupas. Estes resultados indicam que um aumento na dose de inseticida afetou negativamente o T. pretiosum. Portanto, doses mais altas de inseticidas só devem ser usadas quando estritamente necessários para controlar a praga alvo, pois podem comprometer o controle biológico natural de pragas no campo.

Palavras-chave: Controle biológico. Controle químico. MIP. Parasitoide.

\section{Introduction}

For a long time, the effect of selective insecticides on biological control agents has been studied globally (DESNEUX et al., 2007). It has been highlighted as a key strategy for the success of integrated pest management (IPM). However, the selectivity of an insecticide for an organism is directly related to the application rate of the insecticide (DESNEUX et al., 2004). Therefore, when the application rate of an insecticide in field is modified, new studies are necessary to re-evaluate the selectivity of these insecticides for different beneficial organisms. The application rate of an insecticide might vary according to the pest species or crop. For instance, chlorantraniliprole at a rate of $10 \mathrm{~g}$ a.i. ha $\mathrm{h}^{-1}$ has been recommended to control Helicoverpa armigera (Hübner) (Lepidoptera: Noctuidae) in soybean crop. However, an increased rate of chlorantraniliprole 30 g a.i. ha ${ }^{-1}$ has been suggested to control the same pest species in cotton crop. Similarly, chlorantraniliprole + lambda-cyhalothrin $15+7.5 \mathrm{~g}$ a.i. ha ${ }^{-1}$ should be doubled to $30+15 \mathrm{~g}$ a.i. ha $^{-1}$ to control Helicoverpa spp. in maize and cotton, respectively. Spinosad is recommended to control $H$. armigera at the rate of $24 \mathrm{~g}$ a.i. ha ${ }^{-1}$ in soybean but this rate must be increased to $60 \mathrm{~g}$ a.i. $\mathrm{ha}^{-1}$ in cotton to control the same pest species (AGROFIT, 2017). Therefore, the selectivity of an insecticide might vary according to the rate of application (BUENO et al., 2017). Furthermore, growers usually increase the application rate under different situations, such as: 1) when the current rate of application is no longer effective due to the selection of resistant pests or 2) when a new species that is naturally more tolerant to insecticides becomes a significant pest to a specific crop or region (QUINTELA, 2001). Because of this dynamic scenario, studies evaluating the effect of different rates of insecticide applied on the biological control agents are of theoretical and practical interest.

Among different crops, soybean [(Glycine $\max ($ L.) Merrill] is one of the largest and most important crops worldwide in which insecticides have been overused to control pest outbreaks 
(OERKE, 2006; FAOSTAT, 2013). Brazil is the second largest producer of soybean in the world (USDA, 2016). The Brazilian use of insecticides increased considerably in 2013 due to the detection of new pest species in the country (POMARIFERNANDES et al., 2015). Helicoverpa armigera, which is considered one of the most prominent pests worldwide (TAY et al., 2013), was detected in Brazil and found to attack different crops, mainly soybean, maize, and cotton (SPECHT et al., 2013). This triggered a more frequent application of insecticides, and also an increase in the application rate. Sometimes the application rate was beyond the rate recommended in IPM, which worsened the pest problem (POMARI-FERNANDES et al., 2015). Since it is important to adopt various control strategies in IPM, studies on selectivity are important to formulate compatible chemical and biological control strategies depending on the application rate of insecticides (BUENO et al., 2017). Among the IPM strategies, the use of the egg parasitoid Trichogramma sp. is widely adopted owing to its ease of rearing and aggressiveness toward pests (PARRA; ZUCCHI, 2004) including H. armigera.
In this sense, the present study aimed to evaluate the selectivity of several insecticides, commonly recommended to manage $H$. armigera, at different rates in the pupae and adults of T. pretiosum Riley (Hymenoptera: Trichogrammatidae) in order to determine the most harmless treatments.

\section{Material and Methods}

The experiment was divided into different bioassays (Table 1) and carried out in a completely randomized design with five replicates under controlled conditions $\left[25 \pm 2{ }^{\circ} \mathrm{C}, 70 \pm 10 \%\right.$ relative humidity $(\mathrm{RH}), 14: 10 \mathrm{~h}$ light/ dark (L/D) photoperiod] according to the protocol proposed by the International Organization for Biological Control (IOBC) (HASSAN, 1992), which has been briefly described below. The treatments (Table 1) included different rates of the insecticides used to control $H$. armigera in different crops to evaluate selectivity differences at different application rates. The treatments were diluted in water to a spray volume of $200 \mathrm{~L} \mathrm{ha}^{-1}$.

Table 1. Insecticides tested against the egg parasitoid Trichogramma pretiosum under controlled conditions in the laboratory.

\begin{tabular}{|c|c|c|c|c|c|c|}
\hline Bioassay & $\begin{array}{c}\text { Active ingredient } \\
\text { (a.i.) }\end{array}$ & $\begin{array}{l}\text { Commercial } \\
\text { product (CP) }\end{array}$ & Chemical group & $\mathbf{C}^{1}$ & $\begin{array}{c}\mathrm{mL} \mathrm{of} \mathrm{CP} \\
\mathrm{ha}^{-1}\end{array}$ & $\begin{array}{l}\text { g a.i. } \\
\text { ha }^{-1}\end{array}$ \\
\hline \multirow{8}{*}{ 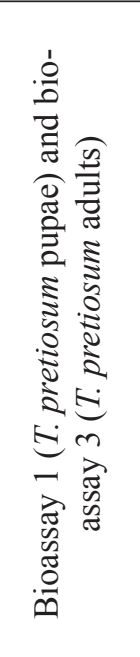 } & Chlorantraniliprole & Premio & Diamide & 200 & 50 & 10 \\
\hline & Chlorantraniliprole & Premio & Diamide & 200 & 75 & 15 \\
\hline & Chlorantraniliprole & Premio & Diamide & 200 & 100 & 20 \\
\hline & Chlorantraniliprole & Premio & Diamide & 200 & 150 & 30 \\
\hline & Chlorantraniliprole & Premio & Diamide & 200 & 250 & 50 \\
\hline & $\begin{array}{l}\text { Chlorantraniliprole } \\
+ \text { lambda-cyhalo- } \\
\text { thrin }\end{array}$ & Ampligo & $\begin{array}{l}\text { Diamide }+ \text { pyre- } \\
\text { throid }\end{array}$ & $100+50$ & 100 & $10+5$ \\
\hline & $\begin{array}{c}\text { Chlorantraniliprole } \\
+ \text { lambda-cyhalo- } \\
\text { thrin }\end{array}$ & Ampligo & $\begin{array}{l}\text { Diamide }+ \text { pyre- } \\
\text { throid }\end{array}$ & $100+50$ & 300 & $30+15$ \\
\hline & $\begin{array}{c}\text { Chlorantraniliprole } \\
\text { + lambda-cyhalo- } \\
\text { thrin }\end{array}$ & Ampligo & $\begin{array}{l}\text { Diamide }+ \text { pyre- } \\
\text { throid }\end{array}$ & $100+50$ & 500 & $50+25$ \\
\hline
\end{tabular}


continuation

\begin{tabular}{|c|c|c|c|c|c|c|}
\hline \multirow{7}{*}{ 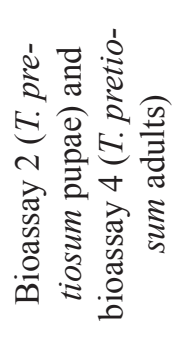 } & Spinosad & Tracer $480 \mathrm{SC}$ & Spinosyns & 480 & 50 & 24 \\
\hline & Spinosad & Tracer $480 \mathrm{SC}$ & Spinosyns & 480 & 125 & 60 \\
\hline & Spinosad & Tracer $480 \mathrm{SC}$ & Spinosyns & 480 & 200 & 96 \\
\hline & Chlorfenapyr & Pirate & Pirazol & 240 & 800 & 192 \\
\hline & Chlorfenapyr & Pirate & Pirazol & 240 & 1000 & 240 \\
\hline & Chlorfenapyr & Pirate & Pirazol & 240 & 1200 & 288 \\
\hline & Chlorfenapyr & Pirate & Pirazol & 240 & 1400 & 336 \\
\hline
\end{tabular}

${ }^{1}$ Concentration of the active ingredient in $\mathrm{g} \mathrm{L}^{-1}$.

\section{Bioassays 1 and 2 (T. pretiosum pupae)}

Tests were conducted using a square cardboard $\left(1 \mathrm{~cm}^{2}\right)$ containing about 400 eggs of Anagasta kuehniella Zeller (Lepidoptera: Pyralidae) with the pupae of T. pretiosum. Initially, this cardboard containing unparasitized eggs of A. kuehniella was offered to the freshly emerged females of the parasitoid for $24 \mathrm{~h}$ for oviposition. The card was then transferred to a tube until the pupae stage (168$192 \mathrm{~h}$ after parasitism) (CÔNSOLI et al., 1999). The pupae were then sprayed directly with the respective treatments (Table 1) using a potter tower calibrated to deposit $1.25 \pm 0.25 \mathrm{mg} \mathrm{cm}^{2}$ (HASSAN, 1992). The applied volume was then verified according to Carmo et al. (2010). The card was placed under ambient conditions for a period of 1-2 $\mathrm{h}$ for drying. Subsequently, the card was inserted in a study cage (HASSAN, 1992). On 1-, 2-, and 3-day(s) after emergence (DAE) of first adults, the cardboard with approximately $200 \mathrm{~A}$. kuehniella eggs was offered to the parasitoids with droplets of honey. The card was removed from the cage 4-DAE of parasitoids, and stored in a transparent plastic bag under controlled conditions $\left(25 \pm 2{ }^{\circ} \mathrm{C}, 70 \pm 10 \% \mathrm{RH}, 14: 10 \mathrm{~h} \mathrm{~L} / \mathrm{D}\right.$ photoperiod) to evaluate parasitism and parasitoid emergence.

\section{Bioassays 3 and 4 (T. pretiosum adults)}

The treatment was sprayed directly on a glass plate $(2 \mathrm{~mm}$ thick and with an area of $13 \mathrm{~cm} \times$ $13 \mathrm{~cm}$ ), similar to the procedure described for the pupae. After the treatment, the plate was placed at an ambient temperature for 1-2 $\mathrm{h}$ for drying. The plate was then coated with a dried film of insecticide and placed in the study cage (HASSAN, 1992). Adults were introduced into the cage via a connection in the emergence tube. Each tube contained a circular white cardboard ( $1 \mathrm{~cm}$ radius) with $200 \pm 50$ eggs of A. kuehniella previously parasitized by $T$. pretiosum. The tube with active, 24 h-old parasitoid adults, previously fed with honey, was connected to the contact cage allowing the parasitoids to enter. On 1-, 2-, and 3-day(s) after the release of parasitoids, the cardboard holding approximately 200 unparasitized A. kuehniella eggs was offered to the parasitoids inside the cage. The card was removed from the cage 4-days after the release of parasitoids and stored in a transparent plastic bag under controlled conditions $\left(25 \pm 2^{\circ} \mathrm{C}, 70 \pm 10 \% \mathrm{RH}, 14: 10 \mathrm{~h} \mathrm{~L} / \mathrm{D}\right.$ photoperiod) until parasitoid emergence to evaluate parasitism and parasitoid emergence later.

\section{Statistical analysis}

The assumption of normality (SHAPIRO; WILK, 1965) and homogeneity of variance of all the treatments (BURR; FOSTER, 1972) were tested. When the data did not follow normality or homogeneity of variance, they were transformed prior analysis of variance (ANOVA). Means were compared by the Tukey's test $(p \leq 0.05)$ for statistical significance (SAS INSTITUTE, 2009). Furthermore, a decrease in emergence or 
parasitism of $T$. pretiosum was compared with the that of the control treatment and was computed by the equations: 1) Percent of decrease in adult emergence $(\mathrm{EP})=(1$ - adult emergence in treatment $/$ adult emergence in control $) \times 100$ (CARMO et al., 2010); and 2) Percent of decrease of parasitism (E) $=(1-$ parasitism in treatment $/$ parasitism in control $)$ $\times 100$ (HASSAN, 1992). The chemicals were classified according to the IOBC standards as: class 1 , harmless $(\mathrm{EP} / \mathrm{E}<30 \%)$; class 2, slightly harmful $(30 \% \leq \mathrm{EP} / \mathrm{E} \leq 79 \%)$; class 3, moderately harmful $(80 \% \leq \mathrm{EP} / \mathrm{E} \leq 99 \%)$; and class 4 , harmful $(\mathrm{EP} / \mathrm{E}>$ 99\%) (HASSAN, 1992).

\section{Results}

Trichogramma pretiosum emergence from the pupae treated with chlorantraniliprole was comparable to that of the negative control (water) despite of the application rate, which ranged from 10 to $50 \mathrm{~g}$ a.i. ha ${ }^{-1}$ (Table 2). Furthermore, the parasitism capacity of the adults was similar to that of the negative control (water) on 1-, 2-, and 3-DAE. The parasitism and emergence of parasitoids of the following generation $\left(\mathrm{P}_{1}\right)$ did not differ from that of the control (Table 2). Therefore, the treatment with chlorantraniliprole was classified as class 1 to $T$. pretiosum on all the days evaluated (Table 3). However, parasitoid emergence was affected in pupae treated with chlorantraniliprole + lambdacyhalothrin (Table 2). The highest evaluated rate of chlorantraniliprole + lambda-cyhalothrin $(50+25$ $\mathrm{g}$ a.i. $\mathrm{ha}^{-1}$ ) reduced the emergence of $T$. pretiosum from the pupae, and also the parasitism capacity of its progeny (second generation $\mathrm{P}_{0}$ ) 1 - and 3-DAE. Therefore, it was classified as class 2 (Table 3).

Table 2. Trichogramma pretiosum emergence from the pupae treated with different insecticides and the parasitism capacity of the emerged adults (second generation) 1-, 2-, and 3-day(s) after emergence (DAE) $\left(25 \pm 2{ }^{\circ} \mathrm{C}, 70 \pm 10 \%\right.$ relative humidity, 14:10 $\mathrm{h} \mathrm{L} / \mathrm{D}$ photoperiod).

\begin{tabular}{|c|c|c|c|c|c|c|c|}
\hline \multirow{3}{*}{$\begin{array}{l}\text { Treatment } \\
\left(\mathrm{g} \text { a.i. } \mathrm{ha}^{-1}\right)\end{array}$} & \multirow{3}{*}{$\begin{array}{l}\text { Parasitoid } \\
\text { emergence } \\
(\%) \text { from } \\
\text { treated } \\
\text { pupae }^{2}\end{array}$} & \multicolumn{6}{|c|}{ Parasitoid progeny $\mathrm{P}_{1}$ (second generation) } \\
\hline & & \multicolumn{2}{|c|}{$1-\mathrm{DAE}^{1}$} & \multicolumn{2}{|c|}{ 2-DAE ${ }^{1}$} & \multicolumn{2}{|c|}{ 3-DAE ${ }^{1}$} \\
\hline & & $\begin{array}{l}\text { Parasitism } \\
(\%)^{2}\end{array}$ & $\begin{array}{c}\text { Parasitoid } \\
\text { emergence } \\
(\%)^{2}\end{array}$ & $\begin{array}{c}\text { Parasitism } \\
(\%)^{2}\end{array}$ & $\begin{array}{c}\text { Parasitoid } \\
\text { emergence } \\
(\%)^{2}\end{array}$ & $\begin{array}{l}\text { Parasitism } \\
\qquad \%)^{2}\end{array}$ & $\begin{array}{c}\text { Parasitoid } \\
\text { emergence } \\
(\%)^{2}\end{array}$ \\
\hline \multicolumn{8}{|c|}{ Bioassay 1} \\
\hline $\begin{array}{c}\text { Chlorantraniliprole } \\
10\end{array}$ & $\begin{array}{l}93.7 \pm \\
0.7 \mathrm{ab}^{3}\end{array}$ & $\begin{array}{c}87.1 \pm \\
5.2 \mathrm{a}\end{array}$ & $\begin{array}{l}98.7 \pm \\
0.4^{\mathrm{ns} ; 3}\end{array}$ & $\begin{array}{l}82.5 \pm \\
5.8^{\mathrm{ns} ; 3}\end{array}$ & $\begin{array}{l}95.5 \pm \\
1.9^{\text {ns;3 }}\end{array}$ & $62.3 \pm 9.9 \mathrm{ab}^{3}$ & $86.6 \pm 12.2^{\mathrm{ns}}$ \\
\hline $\begin{array}{l}\text { Chlorantraniliprole } \\
15\end{array}$ & $97.7 \pm 0.8 \mathrm{a}$ & $\begin{array}{c}85.3 \pm \\
7.5 \mathrm{a}\end{array}$ & $98.0 \pm 1.7$ & $90.2 \pm 2.6$ & $98.9 \pm 0.9$ & $64.0 \pm 6.8 \mathrm{ab}$ & $99.8 \pm 0.2$ \\
\hline $\begin{array}{c}\text { Chlorantraniliprole } \\
20\end{array}$ & $\begin{array}{l}88.9 \pm \\
4.8 \mathrm{ab}\end{array}$ & $\begin{array}{c}86.1 \pm \\
4.1 \mathrm{a}\end{array}$ & $97.7 \pm 2.1$ & $69.3 \pm 8.7$ & $98.2 \pm 1.8$ & $79.7 \pm 4.5 \mathrm{ab}$ & $100.0 \pm 0.0$ \\
\hline $\begin{array}{c}\text { Chlorantraniliprole } \\
30\end{array}$ & $\begin{array}{l}96.8 \pm \\
0.9 \mathrm{ab}\end{array}$ & $\begin{array}{c}78.1 \pm 5.9 \\
a b\end{array}$ & $99.6 \pm 0.3$ & $68.1 \pm 9.9$ & $99.4 \pm 0.4$ & $67.5 \pm 9.1 \mathrm{ab}$ & $99.1 \pm 0.6$ \\
\hline $\begin{array}{l}\text { Chlorantraniliprole } \\
50\end{array}$ & $\begin{array}{l}95.8 \pm \\
1.4 \mathrm{ab}\end{array}$ & $\begin{array}{c}83.7 \pm \\
2.8 \mathrm{a}\end{array}$ & $98.9 \pm 0.8$ & $78.8 \pm 3.7$ & $99.6 \pm 0.4$ & $84.6 \pm 0.5 \mathrm{a}$ & $97.1 \pm 2.1$ \\
\hline $\begin{array}{c}\text { Chlorantraniliprole } \\
10+\text { lambda-cyha- } \\
\text { lothrin } 5\end{array}$ & $\begin{array}{l}91.0 \pm \\
2.7 \mathrm{ab}\end{array}$ & $\begin{array}{c}85.3 \pm \\
4.1 \mathrm{a}\end{array}$ & $96.4 \pm 2.1$ & $81.0 \pm 4.2$ & $93.8 \pm 4.3$ & $66.0 \pm 7.1 \mathrm{ab}$ & $92.8 \pm 5.2$ \\
\hline
\end{tabular}

continue 
continuation

\begin{tabular}{|c|c|c|c|c|c|c|c|}
\hline $\begin{array}{l}\text { Chlorantraniliprole } \\
\text { 30+ lambda-cyha- } \\
\text { lothrin } 15\end{array}$ & $\begin{array}{c}88.3 \pm \\
3.3 b\end{array}$ & $\begin{array}{c}88.4 \pm \\
1.9 \mathrm{a}\end{array}$ & $94.4 \pm 2.8$ & $82.1 \pm 7.5$ & $91.1 \pm 2.8$ & $72.1 \pm 10.6 \mathrm{ab}$ & $86.6 \pm 6.7$ \\
\hline $\begin{array}{l}\text { Chlorantraniliprole } \\
50+\text { lambda-cyha- } \\
\text { lothrin } 25\end{array}$ & $65.6 \pm 5.5 \mathrm{c}$ & $\begin{array}{l}62.6 \pm \\
3.6 \mathrm{~b}\end{array}$ & $85.8 \pm 7.5$ & $62.0 \pm 14.3$ & $98.0 \pm 1.8$ & $47.7 \pm 9.2 b$ & $86.4 \pm 7.5$ \\
\hline $\begin{array}{l}\text { Negative control } \\
\text { (water) }\end{array}$ & $\begin{array}{c}95.8 \pm \\
0.9 \mathrm{~b}\end{array}$ & $\begin{array}{c}91.6 \pm \\
1.9 \mathrm{a}\end{array}$ & $91.1 \pm 5.6$ & $80.4 \pm 7.4$ & $98.1 \pm 1.7$ & $86.4 \pm 2.9 a$ & $88.7 \pm 7.0$ \\
\hline $\begin{array}{l}\text { Positive control } \\
\text { (chlorpyrifos } 480 \text { ) }\end{array}$ & $0.0 \pm 0.0 \mathrm{c}$ & -4 & -4 & -4 & -4 & -4 & -4 \\
\hline $\mathrm{F}$ & 118.83 & 4.38 & 0.84 & 1.15 & 2.10 & 2.82 & 1.37 \\
\hline$p$ & $<0.0001$ & 0.0013 & 0.5750 & 0.3572 & 0.0659 & 0.0185 & 0.2478 \\
\hline $\mathrm{CV}(\%)$ & 7.64 & 10.92 & 10.88 & 22.97 & 8.75 & 16.98 & 15.46 \\
\hline \multicolumn{8}{|c|}{ Bioassay 2} \\
\hline Spinosad 24 & $\begin{array}{l}32.5 \pm \\
6.8 b c^{3}\end{array}$ & $\begin{array}{c}58.9 \pm \\
5.1 \mathrm{bc}\end{array}$ & $\begin{array}{l}97.6 \pm \\
1.5^{\mathrm{ns} ; 3}\end{array}$ & $43.3 \pm 5.1 b$ & $93.9 \pm 4.0^{\mathrm{ns} ; 3}$ & $17.8 \pm 2.1 b$ & $\begin{array}{c}95.9 \pm 4.1 \\
\mathrm{a}^{3}\end{array}$ \\
\hline Spinosad 60 & $\begin{array}{c}22.8 \pm 3.8 \\
\text { bc }\end{array}$ & $9.1 \pm 3.6 \mathrm{e}$ & $92.0 \pm 8.0$ & $6.1 \pm 3.8 \mathrm{~cd}$ & $100.0 \pm 0.0$ & $3.7 \pm 2.2 \mathrm{~cd}$ & $\begin{array}{l}36.8 \pm \\
0.0 \mathrm{~b}\end{array}$ \\
\hline Spinosad 96 & $15.7 \pm 1.5 \mathrm{c}$ & $5.6 \pm 3.2 \mathrm{e}$ & $97.1 \pm 2.9$ & $0.4 \pm 0.4 \mathrm{~d}$ & $100.0 \pm 0.0$ & $0.8 \pm 0.8 \mathrm{~d}$ & $\begin{array}{c}80.0 \pm \\
0.0 \mathrm{ab}\end{array}$ \\
\hline Chlorfenapyr 192 & $\begin{array}{c}35.4 \pm \\
4.6 b\end{array}$ & $88.2 \pm 2.2 \mathrm{a}$ & $100.0 \pm 0.0$ & $18.7 \pm 3.4 c$ & $98.6 \pm 1.4$ & $5.6 \pm 3.3 \mathrm{~cd}$ & $\begin{array}{c}100.0 \pm \\
0.0 \mathrm{a}\end{array}$ \\
\hline Chlorfenapyr 240 & $\begin{array}{c}29.3 \pm \\
4.1 \mathrm{bc}\end{array}$ & $\begin{array}{l}72.5 \pm \\
5.2 \mathrm{ab}\end{array}$ & $97.6 \pm 1.7$ & $0.0 \pm 0.0 \mathrm{~d}$ & -4 & $11.1 \pm 0.9 b c$ & $\begin{array}{c}100.0 \pm \\
0.0 \mathrm{a}\end{array}$ \\
\hline Chlorfenapyr 288 & $\begin{array}{l}24.8 \pm \\
2.1 \mathrm{bc}\end{array}$ & $\begin{array}{l}52.7 \pm \\
4.6 \mathrm{~cd}\end{array}$ & $100.0 \pm 0.0$ & $2.8 \pm 1.8 \mathrm{~d}$ & $100.0 \pm 0.0$ & $0.0 \pm 0.0 \mathrm{~d}$ & -4 \\
\hline Chlorfenapyr 336 & $\begin{array}{l}40.4 \pm \\
3.7 b\end{array}$ & $\begin{array}{c}38.4 \pm \\
1.1 \mathrm{~d}\end{array}$ & $99.1 \pm 0.5$ & $0.6 \pm 0.6 \mathrm{~d}$ & $96.4 \pm 3.6$ & $0.9 \pm 0.9 \mathrm{~d}$ & $\begin{array}{c}100.0 \pm \\
0.0 \mathrm{a}\end{array}$ \\
\hline $\begin{array}{l}\text { Negative control } \\
\text { (water) }\end{array}$ & $84.4 \pm 3.0 \mathrm{a}$ & $85.5 \pm 3.9 \mathrm{a}$ & $98.2 \pm 1.8$ & $77.4 \pm 3.9 \mathrm{a}$ & $99.6 \pm 0.4$ & $76.4 \pm 1.4 \mathrm{a}$ & $\begin{array}{l}93.4 \pm \\
4.3 \mathrm{ab}\end{array}$ \\
\hline $\begin{array}{l}\text { Positive control } \\
\text { (chlorpyrifos } 480 \text { ) }\end{array}$ & $0.0 \pm 0.0 \mathrm{~d}$ & -4 & -4 & -4 & -4 & -4 & -4 \\
\hline $\mathrm{F}$ & 49.02 & 64.06 & 1.06 & 84.36 & 0.67 & 219.47 & 3.48 \\
\hline$p$ & $<0.0001$ & $<0.0001$ & 0.4180 & $<0.0001$ & 0.6762 & $<0.0001$ & 0.0401 \\
\hline $\mathrm{CV}(\%)$ & 16.76 & 16.40 & 7.84 & 35.35 & 9.84 & 26.74 & 14.02 \\
\hline
\end{tabular}

${ }^{1}$ Days after parasitoid emergence (DAE); ${ }^{2}$ Means \pm SE followed by the same letter in each column are not statistically different according to the Tukey's test $(p \geq 0.05)$; ${ }^{3}$ Original data followed by statistics done on the data converted to arcsin $\sqrt{X / 100}$ to perform ANOVA according to Burr and Foster (1972); ${ }^{4}$ Value nonexistent; ${ }^{\text {ns }}$ ANOVA non-significant.

The effects of pesticide on the adults of $T$. pretiosum (bioassays 3 and 4) were different from those on the pupae. Parasitism of the adults that had contact with chlorantraniliprole was similar to the control 1-DAE (Table 4), therefore this treatment was classified as class 1 (Table 3). Parasitism was reduced by chlorantraniliprole at rates of $15,20,30$, and $50 \mathrm{~g}$ a.i. ha ${ }^{-1}$ 2-DAE, and by chlorantraniliprole 20, 30, and $50 \mathrm{~g}$ a.i. ha ${ }^{-1}$ 3-DAE (Table 4). These treatments were classified as slightly class 2 (Table $3)$. The effect of chlorantraniliprole + lambdacyhalothrin on the parasitoid adults was high (Table 4). The treatments with this mixture were classified as class 3 to class 4 (Table 3 ). 
Table 3. Classification of insecticide selectivity for Trichogramma pretiosum according to the International Organization for Biological Control (IOBC) in different bioassays and days after emergence (DAE) of adults or days after spraying (DAS) $\left(25 \pm 2^{\circ} \mathrm{C}, 70 \pm 10 \%\right.$ relative humidity, $14: 10 \mathrm{~h} \mathrm{~L} / \mathrm{D}$ photoperiod).

\begin{tabular}{|c|c|c|c|c|c|c|c|c|c|c|c|c|c|c|}
\hline \multirow{3}{*}{$\begin{array}{l}\text { Treatment } \\
\left(\mathrm{g} \text { a.i. ha }{ }^{-1}\right)\end{array}$} & \multicolumn{8}{|c|}{$\begin{array}{l}\text { Bioassays with pupae } \\
\text { (bioassay } 1 \text { and } 2 \text { ) }\end{array}$} & \multicolumn{6}{|c|}{$\begin{array}{l}\text { Bioassays with adults } \\
\text { (bioassay } 3 \text { and 4) }\end{array}$} \\
\hline & \multicolumn{2}{|c|}{$\begin{array}{l}\text { Sprayed } \\
\text { pupae }\end{array}$} & \multicolumn{2}{|c|}{ 1-DAE } & \multicolumn{2}{|c|}{ 2-DAE } & \multicolumn{2}{|c|}{ 3-DAE } & \multicolumn{2}{|c|}{ 1-DAS } & \multicolumn{2}{|c|}{ 2-DAS } & \multicolumn{2}{|c|}{ 3-DAS } \\
\hline & $\mathrm{EP} \%{ }^{1}$ & $\mathrm{C}^{3}$ & $\mathrm{E} \%{ }^{2}$ & $\mathrm{C}^{3}$ & $\mathrm{E} \%{ }^{2}$ & $\mathrm{C}^{3}$ & $\mathrm{E} \%{ }^{1}$ & $\mathrm{C}^{2}$ & $\mathrm{E} \%{ }^{2}$ & $\mathrm{C}^{3}$ & $\mathrm{E} \%{ }^{2}$ & $\mathrm{C}^{3}$ & $\mathrm{E} \%{ }^{2}$ & $\mathrm{C}^{3}$ \\
\hline & \multicolumn{8}{|c|}{ Bioassay 1} & \multicolumn{6}{|c|}{ Bioassay 3} \\
\hline Chlorantraniliprole 10 & 2.1 & 1 & 4.9 & 1 & 0 & 1 & 27.9 & 1 & 0 & 1 & 14.5 & 1 & 17.2 & 1 \\
\hline Chlorantraniliprole 15 & 0 & 1 & 6.8 & 1 & 0 & 1 & 26.0 & 1 & 27.9 & 1 & 35.2 & 2 & 11.0 & 1 \\
\hline Chlorantraniliprole 20 & 7.2 & 1 & 6.0 & 1 & 13.8 & 1 & 7.7 & 1 & 14.8 & 1 & 44.0 & 2 & 50.6 & 2 \\
\hline Chlorantraniliprole 30 & 0 & 1 & 14.8 & 1 & 15.3 & 1 & 21.9 & 1 & 7.3 & 1 & 40.9 & 2 & 73.1 & 2 \\
\hline Chlorantraniliprole 50 & 0 & 1 & 8.6 & 1 & 1.9 & 1 & 2.1 & 1 & 2.3 & 1 & 32.8 & 2 & 32.9 & 2 \\
\hline $\begin{array}{c}\text { Chlorantraniliprole } 10+ \\
\text { lambda-cyhalothrin } 5\end{array}$ & 5.0 & 1 & 6.9 & 1 & 0 & 1 & 23.7 & 1 & 83.7 & 3 & 85.9 & 3 & 97.8 & 3 \\
\hline $\begin{array}{l}\text { Chlorantraniliprole } 30+ \\
\text { lambda-cyhalothrin } 15\end{array}$ & 7.8 & 1 & 3.4 & 1 & 0 & 1 & 16.6 & 1 & 97.3 & 3 & 99.4 & 4 & 83.3 & 3 \\
\hline $\begin{array}{l}\text { Chlorantraniliprole } 50+ \\
\text { lambda-cyhalothrin } 25\end{array}$ & 31.5 & 2 & 31.7 & 2 & 22.8 & 1 & 44.8 & 2 & 93.6 & 3 & 99.3 & 4 & 100 & 4 \\
\hline \multirow[t]{2}{*}{$\begin{array}{c}\text { Positive control } \\
\text { (chlorpyrifos } 480 \text { ) }\end{array}$} & 100 & 4 & -4 & -4 & -4 & -4 & -4 & -4 & 100 & 4 & 100 & 4 & 100 & 4 \\
\hline & \multicolumn{8}{|c|}{ Bioassay 2} & \multicolumn{6}{|c|}{ Bioassay 4} \\
\hline Spinosad 24 & 61.5 & 2 & 31.1 & 2 & 44.1 & 2 & 76.7 & 2 & 2.6 & 1 & 3.0 & 1 & 9.5 & 1 \\
\hline Spinosad 60 & 73.0 & 2 & 89.4 & 3 & 92.1 & 3 & 95.2 & 3 & 11.2 & 1 & 17.6 & 1 & 26.3 & 1 \\
\hline Spinosad 96 & 81.3 & 3 & 93.5 & 3 & 99.5 & 4 & 99.0 & 3 & 4.3 & 1 & 9.8 & 1 & 9.4 & 1 \\
\hline Chlorfenapyr 192 & 58.0 & 2 & 0 & 1 & 75.8 & 2 & 92.7 & 3 & 0 & 1 & 12.5 & 1 & 22.4 & 1 \\
\hline Chlorfenapyr 240 & 65.3 & 2 & 15.2 & 1 & 100 & 4 & 85.5 & 3 & 0 & 1 & 12.1 & 1 & 25.5 & 1 \\
\hline Chlorfenapyr 288 & 70.6 & 2 & 38.4 & 2 & 96.3 & 3 & 100 & 4 & 6.6 & 1 & 10.8 & 1 & 26.5 & 1 \\
\hline Chlorfenapyr 336 & 52.2 & 2 & 55.1 & 2 & 99.2 & 4 & 98.8 & 3 & 14.1 & 1 & 25.5 & 1 & 59.7 & 2 \\
\hline $\begin{array}{l}\text { Positive control } \\
\text { (chlorpyrifos } 480 \text { ) }\end{array}$ & 100 & 4 & -4 & -4 & -4 & -4 & -4 & -4 & 100 & 4 & 100 & 4 & 100 & 4 \\
\hline
\end{tabular}

${ }^{1} \mathrm{EP}($ Percent of reduction in adult emergence $)=(1-$ Treatment adult emergence $/$ Control adult emergence $\left.) \times 100\right)(\mathrm{CARMO}$ et al., 2010); ${ }^{2} \mathrm{E}$ (Percent of reduction in parasitism $)=(1-$ Treatment parasitism / Control parasitism $) \times 100(\mathrm{HASSAN}, 1992)$; ${ }^{3}$ Classification: class $1=$ harmless $(\mathrm{E} / \mathrm{EP}<30 \%)$, class $2=$ slightly harmful $(30 \% \leq \mathrm{E} / \mathrm{EP}<80)$, class $3=$ moderately harmful $(80 \%$ $\leq \mathrm{E} / \mathrm{EP}<99)$, class $4=$ harmful $(\mathrm{E} / \mathrm{EP} \geq 99 \%)(\mathrm{HASSAN}, 1992) ;{ }^{4}$ Value nonexistent.

The treatment of pupae with spinosad and chlorfenapyr individually reduced parasitoid emergence at all the rates evaluated (Table 2) and were classified as class 2 to class 3 (Table 3 ). Furthermore, the lower parasitism capacity of the parasitoid progeny in all the treatments, except for chlorfenapyr at rates of 192 and $240 \mathrm{~g}$ a.i ha ${ }^{-1}$, was similar to that of the negative control 1-DAE
(Table 2). The negative effect of spinosad on the parasitoid was directly proportional to the evaluated rate, ranging from $24 \mathrm{~g}$ a.i. ha ${ }^{-1}$ (class 2) to $60 \mathrm{~g}$ a.i. ha $^{-1}$ (between class 2 and class 3) to $96 \mathrm{~g}$ a.i. ha ${ }^{-1}$ (between class 3 and class 4) (Table 3). Chlorfenapyr was classified as class 2 when applied on the pupae of the parasitoid (Table 3). Considering its effect on parasitoid progeny that emerged from the treated 
pupae, chlorfenapyr was classified as class 1 to class 2 one-DAE, class 2 to class 3 two-DAE, and class 3 to class 4 three-DAE, with a more harmful effect at higher rates and later evaluations (3-DAE) compared with that of the lower rates and earlier evaluations (1-DAE) (Table 3).

On the contrary, spinosad tested on adults exhibited effects similar to those of the negative control (Table 4), therefore was classified as class 1 for all the treatments (Table 3). Chlorfenapyr was also classified as harmless (class 1 ) to the adults of T. pretiosum, except at the highest evaluated rate of $336 \mathrm{~g}$ a.i. ha ${ }^{-1}$, which reduced parasitism 3-DAE (Table 4) and was classified as class 2 (Table 3).

Table 4. Trichogramma pretiosum parasitism (\%) after parasitoid emergence (\%) on different days after insecticide spraying (DAS) $\left(25 \pm 2{ }^{\circ} \mathrm{C}, 70 \pm 10 \%\right.$ relative humidity, $14: 10 \mathrm{~h} \mathrm{~L} / \mathrm{D}$ photoperiod $)$.

\begin{tabular}{|c|c|c|c|c|c|c|}
\hline \multirow[b]{2}{*}{$\begin{array}{l}\text { Treatment (g i } \\
\left.\qquad \mathrm{a} \mathrm{ha}^{-1}\right)\end{array}$} & $1-\mathrm{DAS}^{1}$ & & $2-\mathrm{DAS}^{1}$ & & $3-\mathrm{DAS}^{1}$ & \\
\hline & $\begin{array}{l}\text { Parasitism } \\
(\%)^{2}\end{array}$ & $\begin{array}{c}\text { Parasitoid } \\
\text { emergence } \\
(\%)^{2}\end{array}$ & $\begin{array}{l}\text { Parasitism } \\
(\%)^{2}\end{array}$ & $\begin{array}{c}\text { Parasitoid } \\
\text { emergence } \\
(\%)^{2}\end{array}$ & $\begin{array}{l}\text { Parasitism } \\
\qquad(\%)^{2}\end{array}$ & $\begin{array}{l}\text { Parasitoid emer- } \\
\text { gence }(\%)^{2}\end{array}$ \\
\hline
\end{tabular}

\section{Bioassay 3}

Chlorantraniliprole 10

Chlorantraniliprole 15

Chlorantraniliprole 20

Chlorantraniliprole 30

Chlorantraniliprole 50

Chlorantraniliprole $10+$ lambda-cyhalothrin 5

Chlorantraniliprole $30+$ lambda-cyhalothrin 15

Chlorantraniliprole $50+$ lambda-cyhalothrin 25

Negative control (water)

$81.4 \pm 3.7$ a $95.7 \pm 1.7 \mathrm{a}^{3}$ $79.9 \pm 7.1 \mathrm{ab}^{3}$ $86.5 \pm 6.7 \mathrm{a}$ $59.3 \pm 6.3 \mathrm{ab}^{3}$ $86.0 \pm 6.8 a^{3}$ $78.2 \pm 9.0 \mathrm{a}$

$98.3 \pm 1.0 \mathrm{a}$

$60.5 \pm 8.6 b$

$96.4 \pm 3.6$ a

$63.7 \pm 5.1 \mathrm{ab}$

$94.1 \pm 5.7 \mathrm{ab}$

$68.0 \pm 6.6 \mathrm{a}$

$99.3 \pm 0.7 a$

$52.3 \pm 11.3 \mathrm{~b}$

$93.3 \pm 6.7 \mathrm{a}$

$35.3 \pm 6.5 \mathrm{bc}$

$98.7 \pm 1.3 \mathrm{a}$

$74.0 \pm 1.8 \mathrm{a}$

$96.6 \pm 2.2 a$

$55.2 \pm 11.0 \mathrm{~b}$

$94.3 \pm 5.7 \mathrm{a}$

$19.2 \pm 2.9 \mathrm{~cd}$

$98.2 \pm 1.8 \mathrm{a}$

$78.0 \pm 6.7 \mathrm{a}$

$96.7 \pm 2.5 \mathrm{a}$

$62.8 \pm 10.1 b$

$99.4 \pm 0.5 \mathrm{a}$

$48.1 \pm 6.8 \mathrm{ab}$

$87.7 \pm 7.5 \mathrm{ab}$

$13.0 \pm 2.3 b$

$90.5 \pm 9.5 \mathrm{a}$

$13.1 \pm 4.2 \mathrm{c}$

$53.3 \pm 9.6 b$

$1.6 \pm 1.6 \mathrm{e}$

$56.2 \pm 22.9 \mathrm{~b}$

$100.0 \pm 0.0 \mathrm{a}$

$0.6 \pm 0.4 \mathrm{c}$

$100.0 \pm 0.0 \mathrm{a}$

$11.9 \pm 4.9 \mathrm{de}$

$100.0 \pm 0.0 \mathrm{a}$

$5.1 \pm 2.6 b$

$43.7 \pm 6.3 b$

$0.6 \pm 0.4 \mathrm{c}$

$100.0 \pm 0.0 \mathrm{a}$

$0.0 \pm 0.0 \mathrm{e}$

$79.8 \pm 4.8 \mathrm{a}$

$92.2 \pm 4.4 \mathrm{a}$

$93.4 \pm 1.9 \mathrm{a}$

$89.7 \pm 6.7 \mathrm{a}$

$71.6 \pm 5.4 \mathrm{a}$

$90.9 \pm 6.4 \mathrm{ab}$

Positive control (chlorpyrifos 480)

$\mathrm{F}$
$p$
$\mathrm{CV}(\%)$

$0.0 \pm 0.0 \mathrm{~b}$

$-4$

$0.0 \pm 0.0 \mathrm{c}$

$-4$

$0.0 \pm 0.0 \mathrm{e}$

3.55

38.68

1.97

$<0.0001$

7.39

39.69

0.0071

12.65

27.90
17.94 
continuation

\begin{tabular}{|c|c|c|c|c|c|c|}
\hline \multicolumn{7}{|c|}{ Bioassay 4} \\
\hline Spinosad 24 & $90.8 \pm 1.4 \mathrm{a}^{3}$ & $93.1 \pm 4.2^{\mathrm{ns}}$ & $81.8 \pm 6.2 \mathrm{a}$ & $98.9 \pm 0.8^{\mathrm{ns}}$ & $74.6 \pm 6.8 \mathrm{a}^{3}$ & $89.5 \pm 2.5 b$ \\
\hline Spinosad 60 & $82.7 \pm 7.0 \mathrm{a}$ & $98.6 \pm 0.7$ & $69.5 \pm 7.1 \mathrm{a}$ & $99.2 \pm 0.6$ & $60.8 \pm 11.3 \mathrm{ab}$ & $98.5 \pm 0.9 \mathrm{a}$ \\
\hline Spinosad 96 & $89.2 \pm 3.6 \mathrm{a}$ & $98.6 \pm 1.2$ & $76.1 \pm 8.9 \mathrm{a}$ & $98.6 \pm 0.9$ & $74.6 \pm 8.4 \mathrm{a}$ & $96.1 \pm 1.6 \mathrm{ab}$ \\
\hline $\begin{array}{c}\text { Chlorfenapyr } \\
192\end{array}$ & $94.4 \pm 1.7 \mathrm{a}$ & $99.6 \pm 0.4$ & $73.8 \pm 9.3 \mathrm{a}$ & $99.1 \pm 0.9$ & $63.9 \pm 8.9 \mathrm{ab}$ & $98.5 \pm 1.5 \mathrm{a}$ \\
\hline $\begin{array}{c}\text { Chlorfenapyr } \\
240\end{array}$ & $93.5 \pm 2.6 \mathrm{a}$ & $95.2 \pm 4.0$ & $74.2 \pm 5.6 \mathrm{a}$ & $99.1 \pm 0.9$ & $61.4 \pm 12.5 \mathrm{ab}$ & $98.0 \pm 1.2 \mathrm{a}$ \\
\hline $\begin{array}{c}\text { Chlorfenapyr } \\
288\end{array}$ & $87.0 \pm 1.6 \mathrm{a}$ & $99.5 \pm 0.5$ & $75.2 \pm 9.7 \mathrm{a}$ & $94.5 \pm 4.6$ & $60.5 \pm 7.4 \mathrm{ab}$ & $97.8 \pm 1.0 \mathrm{a}$ \\
\hline $\begin{array}{c}\text { Chlorfenapyr } \\
336\end{array}$ & $80.1 \pm 8.3 \mathrm{a}$ & $97.1 \pm 2.0$ & $62.9 \pm 4.3 \mathrm{a}$ & $96.6 \pm 2.1$ & $33.2 \pm 0.8 \mathrm{~b}$ & $95.5 \pm 2.6 \mathrm{ab}$ \\
\hline $\begin{array}{l}\text { Negative con- } \\
\text { trol (water) }\end{array}$ & $93.2 \pm 1.5 \mathrm{a}$ & $92.4 \pm 4.8$ & $84.3 \pm 3.4 \mathrm{a}$ & $96.3 \pm 2.4$ & $82.4 \pm 3.5 \mathrm{a}$ & $99.2 \pm 0.8 \mathrm{a}$ \\
\hline $\begin{array}{l}\text { Positive con- } \\
\text { trol (chlorpyri- } \\
\quad \text { fos } 480 \text { ) }\end{array}$ & $0.0 \pm 0.0 \mathrm{~b}$ & -4 & $0.0 \pm 0.0 \mathrm{~b}$ & -4 & $0.0 \pm 0.0 \mathrm{c}$ & -4 \\
\hline $\mathrm{F}$ & 54.26 & 1.04 & 14.44 & 0.69 & 13.79 & 3.73 \\
\hline$P$ & $<0.0001$ & 0.4215 & $<0.0001$ & 0.6798 & $<0.0001$ & 0.0060 \\
\hline CV (\%) & 11.55 & 6.49 & 22.75 & 4.82 & 24.99 & 3.43 \\
\hline
\end{tabular}

${ }^{1}$ Days after insecticide spraying (DAS); ${ }^{2}$ Means \pm SE followed by the same letter in each column are not statistically different according to the Tukey's test $(p \geq 0.05) ;{ }^{3}$ Original data followed by statistics done on the data converted to arcsin $\sqrt{X / 100}$ to

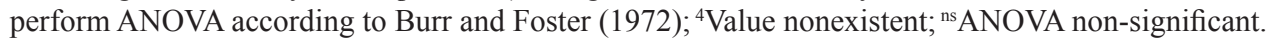

\section{Discussion and Conclusion}

All the evaluated rates of chlorantraniliprole from 10 to $50 \mathrm{~g}$ a.i. ha ${ }^{-1}$ were classified as harmless to the pupae of $T$. pretiosum indicating that it is appropriate for use in IPM programs owing to its negligible effect on the parasitoid at the tested rates. Similar results have been reported in different beneficial arthropods, including the egg parasitoid Trichogramma dendrolimi Matsumura (Hymenoptera: Trichogrammatidae), predatory mite Typhlodromus pyri Scheuten (Acari: Phytoseiidae), and parasitoid Aphidius rhopalosiphi De StefaniPerez (Hymenoptera: Aphidiinae) (DINTER et al., 2008; BRUGGER et al., 2010). This suggests that chlorantraniliprole is harmless not only to $T$. pretiosum pupae, but also to other biological control agents.

The selectivity observed for chlorantraniliprole might be because chlorantraniliprole acts mainly after ingestion (LAHM et al., 2007), therefore limiting its action to phytophagous insects. Chlorantraniliprole acts on the nervous system of an organism by activating the receptors of ryanodine by releasing calcium from the sarcoplasmic reticulum of muscle cells causing paralysis and death of the insect (CORDOVA et al., 2006). However, it does not affect the biological control agent due to the limited ingestion of the insecticide by the beneficial arthropods. Similar results have been observed in Podisus nigrispinus (Hemiptera: Pentatomidae) (STECCA et al., 2017). In the present study, the mixture of chlorantraniliprole and lambda-cyhalothrin affected T. pretiosum more than chlorantraniliprole alone. This is due to the action of lambda-cyhalothrin — an insecticide belonging to the pyrethroid group — which has been reported to be harmful to most beneficial arthropods (CAÑETE, 2005). 
It is noteworthy that the effect of an insecticide can range from harmless to harmful depending on the developmental stage of the parasitoid (SANTOS et al., 2006), as demonstrated in the present study. Chlorantraniliprole at relatively high rates $(20,30$, and $50 \mathrm{~g}$ a.i. ha ${ }^{-1}$ ) was marginally more toxic to the adults than to the pupae. The higher tolerance of the pupae of $T$. pretiosum to the insecticide when compared with that of the adults is synonymous with earlier reports (STECCA et al., 2016). This might be due to the presence of the parasitoid within the host egg where the chorion protects the parasitoid from the insecticide (STECCA et al., 2016). It is also important to note that the ability of an insecticide to penetrate the chorion of an insect egg might vary depending on the physicochemical properties of the tested insecticide. Chemicals with a relatively high molecular weight have a greater difficulty in crossing the chorion (STOCK; HOLLOWAY, 1993). In the present study, an increased tolerance to insecticides was also observed in pupae treated with chlorantraniliprole + lambda-cyhalothrin. On the contrary, the effect of spinosad and chlorfenapyr was higher on the pupae than on the adults. The difference in selectivity of an insecticide during different developmental stages of an insect might be related to the site of action, which can change during development. Thus, affecting the rate of penetration through the integument of an insect and/or rate of metabolization of the insecticide within the insect (BUENO et al., 2017). The rate of insecticide penetrating the integument depends on the relationship between insecticide affinity, cuticle thickness, and chemical composition (FERNANDES et al., 2010), which might differ among the pupae and adults of the same parasitoid species. The lipophilicity of insecticides is inversely proportional to their solubility in water (FERNANDES et al., 2010). Therefore, compounds with a relatively high lipophilicity can penetrate the body of an insect at a relatively high rate due to their similarity with the cuticle that can differ among the pupae and adults of the parasitoid.
Spinosad, a mixture of compounds produced by the bacterium Saccharopolyspora spinosa, is often classified as low risk and less harmful to predators (WILLIAMS et al., 2003). However, parasitoids belonging to the order hymenoptera are significantly susceptible to spinosad (WILLIAMS et al., 2003). Spinosad acts mainly as a stomach poison (BRET et al., 1997) with low contact activity. This might have been responsible for its higher effect on the pupae than on the adults of $T$. pretiosum. In the present study, the adult parasitoids came in contact only with the dry spinosad residue on the cardboard plates inside the study cages (tarsal contamination). Whereas, the parasitoids in pupae test usually eat the chorion of the egg during adult emergence, thus they might have ingested the spinosad residues during emergence.

The effect on $T$. pretiosum varied not only for chlorantraniliprole, but also for the other insecticides tested. In general, an increase in the application rate was directly proportional to the increase in the negative effect of the insecticide on the biological control agent. Chlorantraniliprole at a rate of $10 \mathrm{~g}$ a.i. ha ${ }^{-1}$ was classified as harmless to both the pupae and adults of the parasitoid. However, chlorantraniliprole at rates of 20 to $50 \mathrm{~g}$ a.i. $\mathrm{ha}^{-1}$ was harmless only to the pupae, while it was classified as slightly harmful to the adults of $T$. pretiosum adults. Chlorantraniliprole + lambda-cyhalothrin at a rate of $10+5 \mathrm{~g}$ a.i. ha ${ }^{-1}$ was classified as harmless to the pupae and moderately harmful to the adults of T. pretiosum. On the contrary, the highest tested rate of chlorantraniliprole 50 + lambda-cyhalothrin (25 $\mathrm{g}$ a.i. $\mathrm{ha}^{-1}$ ) was categorized as slightly harmful to the pupae and harmful to the adults of the parasitoid. A similar increase in toxicity was observed with the increasing rates of spinosad and chlorfenapyr. Spinosad at $24 \mathrm{~g}$ a.i. ha ${ }^{-1}$ was slightly harmful and harmless to the pupae and adults of $T$. pretiosum, respectively. Spinosad at a rate of $96 \mathrm{~g}$ a.i. ha ${ }^{-1}$ was classified as moderately harmful and harmful to the pupae of the parasitoid. Chlorfenapyr at 192 g a.i. ha ${ }^{-1}$ was categorized as slightly harmful and 
moderately harmful to the pupae of $T$. pretiosum, while chlorfenapyr at $336 \mathrm{~g}$ a.i. ha ${ }^{-1}$ was classified as slightly harmful and harmful to the same parasitoid stage.

Chlorantraniliprole at a rate of $10 \mathrm{~g}$ a.i. ha ${ }^{-1}$ was harmless (class 1) to both the pupae and adults of $T$. pretiosum. The effect of chlorantraniliprole ranging from 20 to $50 \mathrm{~g}$ a.i. ha ${ }^{-1}$ varied from harmless (class 1) to slightly harmful (class 2) to T. pretiosum adults. Chlorantraniliprole + lambda-cyhalothrin 10 $+5 \mathrm{~g}$ a.i. ha $^{-1}$ was harmless (class 1 ) to the pupae and moderately harmful (class 3 ) to the adults of $T$. pretiosum. On the contrary, the highest tested rate of chlorantraniliprole + lambda-cyhalothrin $(50+25 \mathrm{~g}$ a.i. ha ${ }^{-1}$ ) was categorized as slightly harmful (class 2) to the pupae and harmful (class 4) to the adults of the parasitoid.

Spinosad at a rate of $24 \mathrm{~g}$ a.i. ha $\mathrm{h}^{-1}$ was slightly harmful (class 2) and harmless (class 1) to the pupae and adults of T. pretiosum, respectively. However, spinosad at a rate of $96 \mathrm{~g}$ a.i. ha ${ }^{-1}$ was classified as moderately harmful (class 3 ) and harmful (class 4) to the pupae of the parasitoid.

Chlorfenapyr at a rate of $192 \mathrm{~g}$ a.i. ha ${ }^{-1}$ was classified as slightly harmful (class 2) and moderately harmful (class 3) to the pupae of $T$. pretiosum, whereas chlorfenapyr at $336 \mathrm{~g}$ a.i. ha ${ }^{-1}$ was classified as slightly harmful (class 2) and harmful (class 4) to the same parasitoid stage. An increase in the rate of tested insecticides increased their negative effects on $T$. pretiosum. Therefore, these insecticide rate increases should only be applied when strictly necessary to control the target pest, because they might compromise the biological pest control process in the field.

\section{Acknowledgments}

We would like to thank Embrapa Soja, CNPq and CAPES, for funding the present study. The present study was approved for publication by the Editorial Board of Embrapa Soja.

\section{References}

AGROFIT. Sistemas de agrotóxicos fitossanitários. Available at: <http://extranet.agricultura.gov.br/agrofit cons/principal_agrofit_cons $>$. Accessed at: $17 \mathrm{dec} .2017$. BRET, B. L.; LARSON, L.; SCHOONOVER, J. R.; SPARKS, T. C.; THOMPSON, G. D. Biological properties of spinosad. Down to Earth, New Delhi, v. 52, n. 1, p. 6-13, 1997.

BRUGGER, K. E.; COLE, P. G.; NEWMAN, I. C.; PARKER, N.; SCHOLZ, B.; SUVAGIA, P.; WALKER, G.; HAMMOND, T. G. Selectivity of chlorantraniliprole to parasitoid wasps. Pest Management Science, Sussex, v. 66, n. 10 , p. $1075-1081,2010$. Available at: $<$ http:// onlinelibrary.wiley.com/wol1/doi/10.1002/ ps.1977/ full>. Accessed at: 16 nov. 2016.

BUENO, A. F.; CARVAlHO, G. A.; SANTOS, A. C.; SOSA-GÓMEZ, D. R.; SILVA, D. M. Pesticide selectivity to natural enemies: challenges and constraints for research and field recommendation. Ciência Rural, Santa Maria, v. 47, n. 6, p. 1-8, 2017. Available at: $\quad<\mathrm{http} / / / \mathrm{www}$. scielo.br/scielo.php?script=sci arttext\&pid=S0103-84782017000600157\&lng=en\&tlng $=$ en $>$. Accessed at: 17 dec. 2017.

BURR, I. W.; FOSTER, L. A. A test for equality of variances. West Lafayette: University of Purdue, 1972. 26 p. (Mimeo series, 282).

CAÑETE, C. L. Seletividade de inseticidas a espécies de Trichogramma (Hymenoptera: Trichogrammatidae). 2005. Dissertação (Mestrado em Zoologia) - Universidade Federal do Paraná, Curitiba.

CARMO, E. L.; BUENO, A. F.; BUENO, R. C. O. F. Pesticide selectivity for the insect egg parasitoid Telenomus remus. BioControl, Dordrecht, v. 55, n. 4, p. 455-464, 2010. Available at: <http://link.springer. com/ article/10.1007/s10526-010-9269-y>. Accessed at: 17 mar. 2016.

CÔNSOLI, F. L.; KITAJIMA, E. W.; PARRA, J. R. P. Ultrastructure of the natural and factitious host eggs of Trichogramma galloi Zucchi and Trichogramma pretiosum Riley (Hymenoptera: Trichogrammatidae). International Journal of Insect Morphology and Embryology, Oxford, v. 28, n. 3, p. 211-231, 1999. Available at: <http://www.sciencedirect.com/science/ article/pii/S0020732299000264>. Accessed at: 10 Nov. 2016.

CORDOVA, D.; BENNER, E. A.; SACHER, M. D.; RAUH, J. J.; SOPA, J. S.; LAHM, G. P.; RHOADES, D. F. Anthranilic diamides: a new class of insecticides with a novel mode of action, ryanodine receptor activation. Pesticide Biochemistry and Physiology, Maryland 
Heights, v. 84 , n. 3, p. 196-214, 2006. Available at: $<$ http://www.sciencedirect.com/science/article/pii/ S0048357505000945>. Accessed at: 17 jun. 2016.

DESNEUX, N.; DECOURTYE, A.; DELPUECH, J. M. The sublethal effects of pesticides on beneficial arthropods. Annual Review of Entomology, Stanford, v. 52, p. 81-106, 2007. Available at: <http://annualreviews. org/doi/abs/10.1146/annurev.ento.52.110405.091440>. Accessed at: 14 mar. 2016.

DESNEUX, N.; RAFALIMANANA, H.; KAISER, L. Dose-response relationship in lethal and behavioural effects of different insecticides on the parasitic wasp Aphidius ervi. Chemosphere, Netherlands, v. 54, n. 5, p. 619-627, 2004. Available at: <http://www.sciencedirect. com/science/article/pii/S0045653503008762>. Accessed at: 14 mar. 2016.

DINTER, A.; BRUGGER, K.; BASSI, A.; FROST, N. M.; WOODWARD, M. D. Chlorantraniliprole (DPXE2Y45, DuPont ${ }^{\mathrm{TM}}$ Rynaxypyr $^{\circledR}$, Coragen $^{\circledR}$ and Altacor ${ }^{\circledR}$ insecticide) - a novel anthranilic diamide insecticide demonstrating low toxicity and low risk for beneficial insects and predatory mites. Montfovet: IOBC/WPRS Bulletin, v. 35, p. 128-135, 2008.

FAOstat, Food. Agriculture Organization of the United Nations (Statistical database). 2013.

FERNANDES, F. L.; BACCI, L.; FERNANDES, M. S. Impact and selectivity of insecticides to predators and parasitoids. EntomoBrasilis, v. 3, n. 1, p. 1-10, 2010. Available at: $<$ file:///C:/Users/hp/Downloads/ DialnetImpactAndSelectivityOfInsecticidesToPredatorsAnd Pa-3695220.pdf>. Accessed at: 16 june 2016.

HASSAN, S. A. Guideline for the evaluation of sideeffects of plant protection product on Trichogramma cacoeciae. In: Guidelines for testing the effects of pesticides on beneficial organisms: description of test methods. France: iOBC/WPRS Bulletin, 1992. p. 18-39.

LAHM, G. P.; STEVENSON, T. M.; SELBY, T. P.; FREUDENBERGER, J. H.; CORDOVA, D.; FLEXNER, L.; BELLIN, C. A.; DUBAS, C. M.; SMITH, B. K.; HUGHES, K. A.; HOLLINGSHAUS, J. G.; CLARK, C. E.; BENNER, E. A. Rynaxypyr ${ }^{\mathrm{TM}}$ : a new insecticide anthranilic diamide that acts as a potent and selective ryanodine receptor activator. Bioorganic \& Medicinal Chemistry Letters, Oxford, v. 17, n. 22, p. 6274-6279, 2007. Available at: <http://www.sciencedirect.com/ science/article/pii/S0960894X0701044X > . Accessed at: 14 mar. 2016.

OERKE, E. C. Crop losses to pests. The Journal of Agricultural Science, Terhan, v. 144, n. 1, p. 31-43, 2006. Available at: <http://journals.cambridge.org/action/displ
ayFulltext?type $=6 \&$ fid $=431726 \& \mathrm{jid}=$ AGS\&volumeId $=$ 144\&issueId $=01 \&$ aid $=431724 \&$ bodyId $=\&$ membership Number $=\&$ societyETOCSession $=\&$ fulltextType $=$ RV\&fi leId=S0021859605005708 $>$. Accessed at: 23 may 2016.

PARRA, J. R. P.; ZUCCHI, R. A. Trichogramma in Brazil: feasibility of use after twenty years of research. Neotropical Entomology, Londrina, v. 33, n. 3, p. 271281, 2004. Available at: <http://www.scielo.br/scielo. php? pid=S1519-566X2004000300001\&script $=$ sci arttext>. Accessed at: 25 apr. 2016.

POMARI-FERNANDES, A.; BUENO, A. F.; SOSAGÓMEZ, D. R. Helicoverpa armigera: current status and future perspectives in Brazil. Current Agricultural Science and Technology, Pelotas, v. 21, n. 1, p. 1-7, 2015. Available at: $<$ https://periodicos.ufpel.edu.br/ojs2/index. php/CAST/article/view/4234/0>. Accessed at: 13 dec. 2016.

QUINTELA, E. D. Manejo integrado de pragas do feijoeiro. Santo Antônio de Goiás: EMBRAPA, 2001. 28 p. (Circular técnica).

SANTOS, A. C.; BUENO, A. F.; BUENO, R. C. O. F. Seletividade de defensivos agrícolas aos inimigos naturais. In: PINTO, A. S.; NAVA, D. E.; ROSSI, M. M.; MALERBO-SOUZA, D. T. Controle biológico de pragas na prática. Piracicaba: CP 2, 2006. p. 221-227.

STATISTICAL ANALYSIS SYSTEM INSTITUTE SAS Institute. SAS/STAT ${ }^{\circledR} 9.2$ user's guide, ed. Cary: NC: SAS, 2009.

SHAPIRO, S. S.; WILK, M. B. An analysis of variance test for normality. Biometrika, London, v. 52, n. 3-4, p. 591-611, 1965.

SPECHT, A.; SOSA-GÓMEZ, D. R.; PAULA-MORAES, S. V. de; YANO, S. A. C. Identificação morfológica e molecular de Helicoverpa armigera (Lepidoptera: Noctuidae) e ampliação de seu registro de ocorrência no Brasil. Pesquisa Agropecuária Brasileira, Brasília, v. 48, n. 6, p. 689-692, 2013. Disponível em: <https://seer.sct. embrapa.br/index.php/pab/article/view/15732>. Acesso em: 25 jun. 2016.

STECCA, C. S.; BUENO, A. F.; PASINI, A.; SILVA, D. M.; ANDRADE, K.; FILHO, D. M. Z. Side-effects of glyphosate to the parasitoid Telenomus remus Nixon (Hymenoptera: Platygastridae). Neotropical Entomology, Londrina, v. 45, n. 2, p. 192-200, 2016. Available at: $<$ http://link.springer.com/article/10.1007/ s13744-0160363-4>. Accessed at: 25 apr. 2016.

STECCA, C. S.; SILVA, D. M.; BUENO, A. F.; PASINI, A.; DENEZ, M. D.; ANDRADE, K. Selectivity of insecticides used in soybean crop to the predator Podisus nigrispinus (Hemiptera: Pentatomidae). Semina: 
Ciências Agrárias, Londrina, v. 38, n. 6, p. 3469-3480, 2017. Available at: <http://www.uel.br/revistas/ uel/ index.php/semagrarias/article/view/27796>. Accessed at: 13 dec. 2017.

STOCK, D.; HOLLOWAY, P. J. Possible mechanisms for surfactant-induced foliar uptake of agrochemicals. Pest Management Science, Sussex, v. 38, n. 2-3, p. 165177, 1993. Available at: <http://onlinelibrary.wiley.com/ doi/10.1002/ps.2780380211/pdf $>$. Accessed at: $13 \mathrm{dec}$. 2016.

TAY, W. T.; SORIA, M. F.; WALSH, T.; THOMAZONI, D.; SILVIE, P.; BEHERE, G. T.; ANDERSON, C.; DOWNES, S. A brave new world for an old world pest: Helicoverpa armigera (Lepidoptera: Noctuidae) in Brazil. PLoS One, San Francisco, v. 8, n. 11, p. 1-7, 2013. Available at: <http://journals.plos.org/plosone/ article? id=10.1371/journal.pone.0080134>. Accessed at: 13 apr. 2016.

UNITED STATE DEPARTMENT OF AGRICULTURE - USDA. World agricultural production. Foreign Agricultural Service, 2016. 27 p.

WILLIAMS, T.; JAVIER, V.; ELISA, V. Is the naturally derived insecticide spinosad $\AA$ compatible with insect natural enemies? Biocontrol Science and Technology, Oxford, v. 13, n. 5, p. 459-475, 2003. Available at: $<$ http://www.tandfonline.com/doi/abs/10.1080/0958315 031000140956>. Accessed at: 13 june 2016. 
